\title{
APPLICATIONS OF 3D PRINTING TECHNOLOGIES IN THE GARMENT INDUSTRY
}

\author{
Veronica Verlan, Marcela Irovan \\ Faculty of Textiles and Poligraphy, Technical University of Moldova, Republic of Moldova \\ Blvd. Stefan cel Mare si Sfant, 168, MD 2004, Chisinau, Republic of Moldova \\ e-mail: marcela.irovan@gmail.com
}

\begin{abstract}
The usage of innovative technologies has become one of the most widespread ways of diversifying the current supply of clothing and footwear products. Therefore, using the $3 D$ printing technologies in the garment production is a remarkable example of the symbiosis of creativity and technology, which creates unusual and fashionable clothing pieces. Although the 3D printing technology is a relatively new technology and allows creating unique garments it must not neglect important features of clothing products such as cost-accessibility, comfort and aesthetic appearance. The research on these aspects is prior to implement this technology in the manufacturing process. The study includes the analysis of the current $3 D$ printing technologies which are used for obtaining threedimensional objects, the current directions of implementing this technology in the industry, as well as the opportunities of applying this technology in the process of clothing's creation. Therefore, this paper concludes the study with the creation of a clothing product - a blouse for women, which is including a $3 D$ printed part confirming this way the possibility of creation of clothing products, which would integrate innovative elements which were obtained by implementing the advanced technology of additive manufacturing.
\end{abstract}

Key words: 3D printing technologies, garment production, additive manufacturing.

\section{INTRODUCTION}

The use of 3D printing technology is an illustrative example of the symbiosis between technology and creativity that offers the opportunity to create unusual and unique objects. Although it is an accelerated process of designing and manufacturing, 3D printing represents the ultimate features of printed matter through additive technology. [1-4]

\section{METHODS}

The 3D printing process is done with digital technology by a printer and includes three general steps: creating the object in a three-dimensional CAD software, printing the threedimensional object, and finishing the printing process by cleaning dust and waste generated during the process off the printed object. [1, 2]

This technology can be used in particular to create prototypes and sample models and finds multiple applications in architecture, engineering and construction, industrial design, automotive, furniture, aerospace, dental and medical industries, education, geographic information systems, civil engineering, the jewelry industry and many other areas.

Although this technology is expensive, 3D printing is a pretty favorable option to compete with the traditional methods of clothing fabrication because of the innovation element it brings in the design and the characteristics of the shapes obtained. However, a deeper analysis of the particularities of the integration of technology in the clothing industry outlines several advantages and disadvantages that characterize the possibilities of the additive manufacturing. [3]

IRTITE Vol. 6, No. 2, 2018 ISSN 1314-8788 (print), ISSN 1314-8796 (online), doi: 10.15547/artte.2018.02.005 


\section{IRTTE

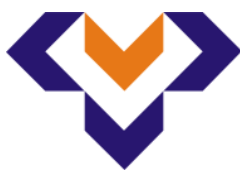 \\ Ipplied Reseirlohes in Technics, Technologies and Bducation \\ Journal of the Faculty of Technics and Technologies, Trakia University https://sites.google.com/a/trakia-uni.bg/artte/}

Although the requirements for producing printed products are quite high, the use of additive technology in the garment industry presents a number of advantages that resists many particularities $[3,4,6]$ :

1) Reduction of production waste quantities.

2) Use of recycled or reused raw material.

3) Wide variety of colors and low pollution.

4) The cost of materials is only reported for the volume of raw material used in production. Due to the preliminary modeling in 3D modeling software, the exact form of objects with minimal material waste is obtained.

5) Getting unique and personalized creations that can take forms that are impossible for traditional technologies.

Some examples of disadvantages using 3D printing technologies in the garment industry can be $[3,4,6]$ :

1) Rigidity of product shape due to limited, rigid and uncomfortable raw material for clothing.

2) The need to have complex knowledge in various areas - clothing design, clothing modeling and technology, 3D modeling in specialized software, knowledge about the properties of chemical materials, 3D printer and printer configuration and usage skills, etc.

3) Complex maintenance of equipment.

4) Longer preparation time than traditional methods.

Thus, 3D printing is a technology that is rapidly developing and appealing to the diversification of the developed models, also being a way of innovation and sustainability of the garment industry, important aspects of contemporary society that is constantly struggling with ecological disasters.

\section{EXPERIMENTAL}

Diversifying clothing patterns is an ongoing issue for the fashion industry. Innovation and the application of a variety of clothing technology are increasingly common in diversifying the supply on the market. The novelty elements of garments are often motivated not only by offering various products as design, most of them being intentions conditioned by the improvement of the fashion industry's sustainability by reducing the negative contribution of the textile and clothing industry to the society and the environment - obtaining textile fibers from recycled materials, harmless dyes or pigments whose use in waste water would not cause ecological disasters, shortening the production cycle by obtaining products through more advanced technologies such as obtaining a complex knitted product in its entirety, and so on.

These directions of the use of innovative technologies and the possibility of bringing innovation elements were the basic directions of the application of the additive technology (3D printing) in the clothing manufacturing technology. 3D printing is a technology quite common at present, its application being researched and tried in various branches of industry, defining enormous possibilities of technology - application in construction, medicine, mechanics, aeronautics, food, architecture, prototyping and even and in the fashion industry, this option being analyzed in this research.

Initially it is proposed to characterize the technology and its aspects for a deeper understanding of the additive manufacturing process and the possibilities of its application in the fabrication of clothing products. Defining these elements will be a prerequisite for analyzing and obtaining structures that could replace traditional woven or knitted textile structures that are used to make garments. After analyzing the structures obtained and observing their properties, it is proposed to perform an analysis of the possibilities of application of the additive technology in the creation of the clothing parts by integrating the printed elements and defining the method of their integration in the textile garments.

IRTITI Vol. 6, No. 2, 2018 ISSN 1314-8788 (print), ISSN 1314-8796 (online), doi: 10.15547/artte.2018.02.005 


\section{IRTIIE Ipplied Researreches in Technics, Technologies and Bduration Journal of the Faculty of Technics and Technologies, Trakia University https://sites.google.com/a/trakia-uni.bg/artte/}

\section{RESULTS}

In the course of the research we have identified possibilities of applying the 3D printing technology in the process of creating the clothing products, a clothing product has been made that integrates a mark obtained through 3D printing (Figure 1). [5, 6]
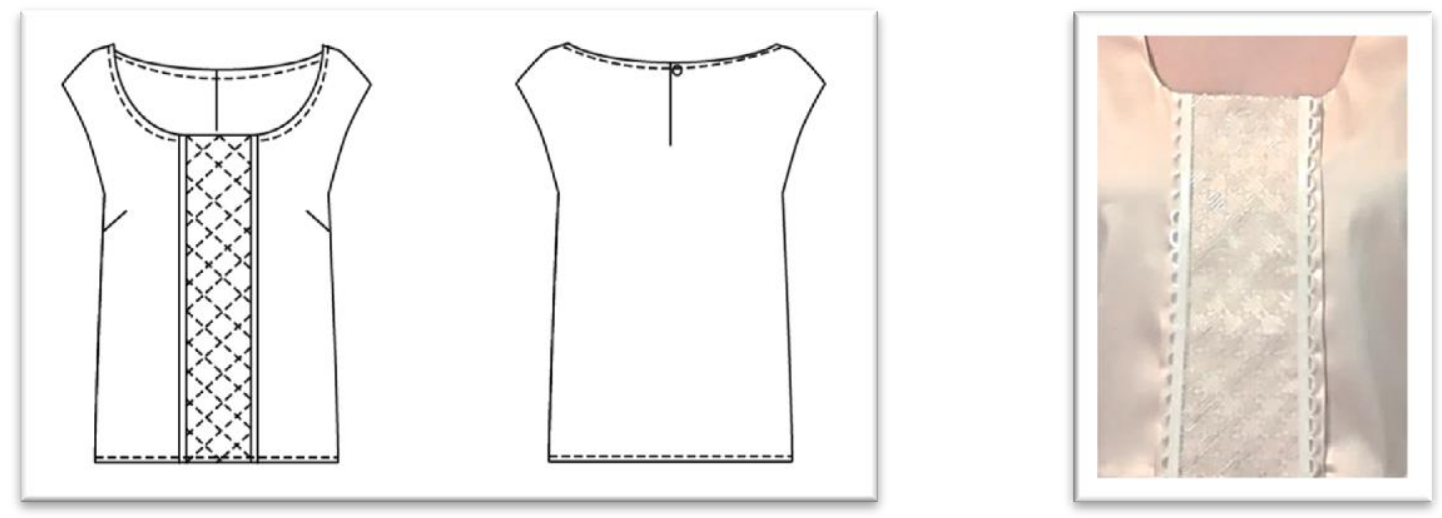

Figure 1. The developed product

Previous steps of the product assembly were the analysis of the additive manufacturing process and the specificity of the $3 \mathrm{D}$ printers, applications of the technology under the current conditions of the industry, as well as its existing applications in the fashion industry. These stages constituted prerequisites for carrying out the research applications, namely samples of structures that could replace the traditional textiles structures existing in the garment industry.

The elaboration of the structures allowed the definition of an example of a structure that would allow its integration into a clothing product, thus developing a system of models that would have included within the product markings obtained by the additive manufacture.

From the elaborated system was chosen a model that was made and exposed to the subsequent studies of achieving of the three-dimensional markers for printing. Printed printers require special software that allows the creation of three-dimensional objects and subsequent processing of files in a program of another type that prepares the object to launch the process to the printer (Figure 2, Figure 3). [5, 6]
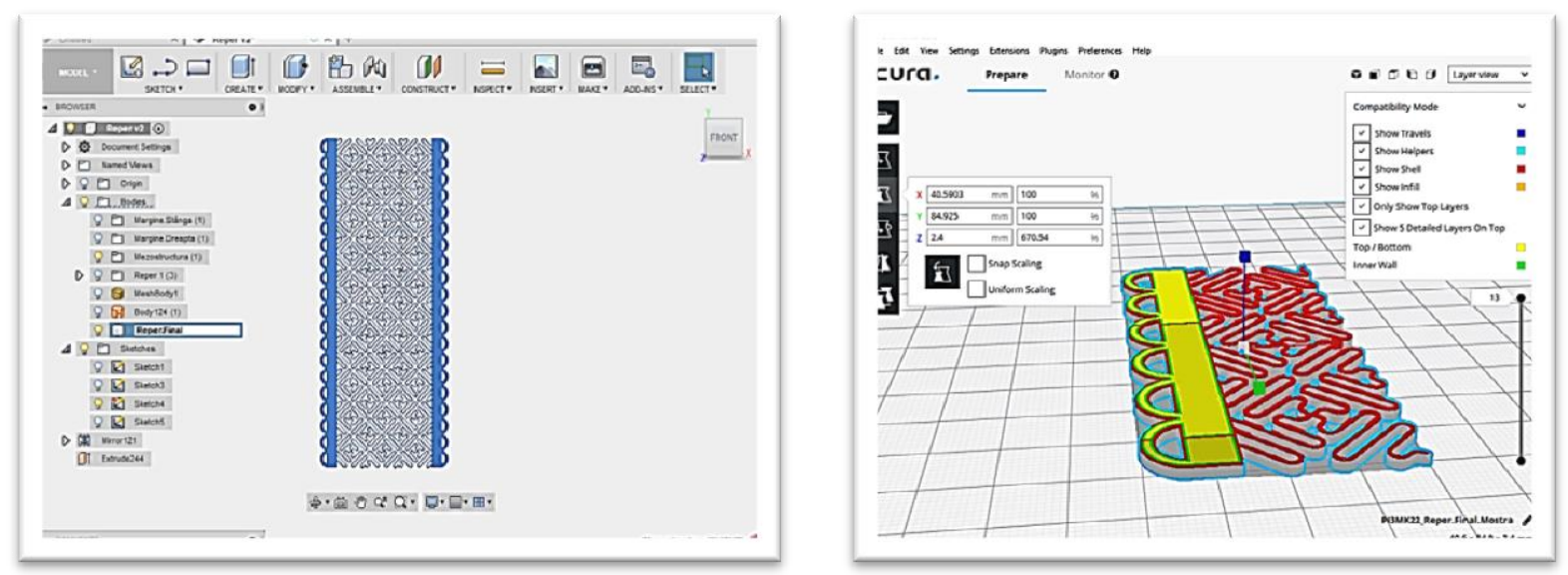

Figure 2. Designing the benchmark through 3D printing technology

IRITIE Vol. 6, No. 2, 2018 ISSN 1314-8788 (print), ISSN 1314-8796 (online), doi: 10.15547/artte.2018.02.005 

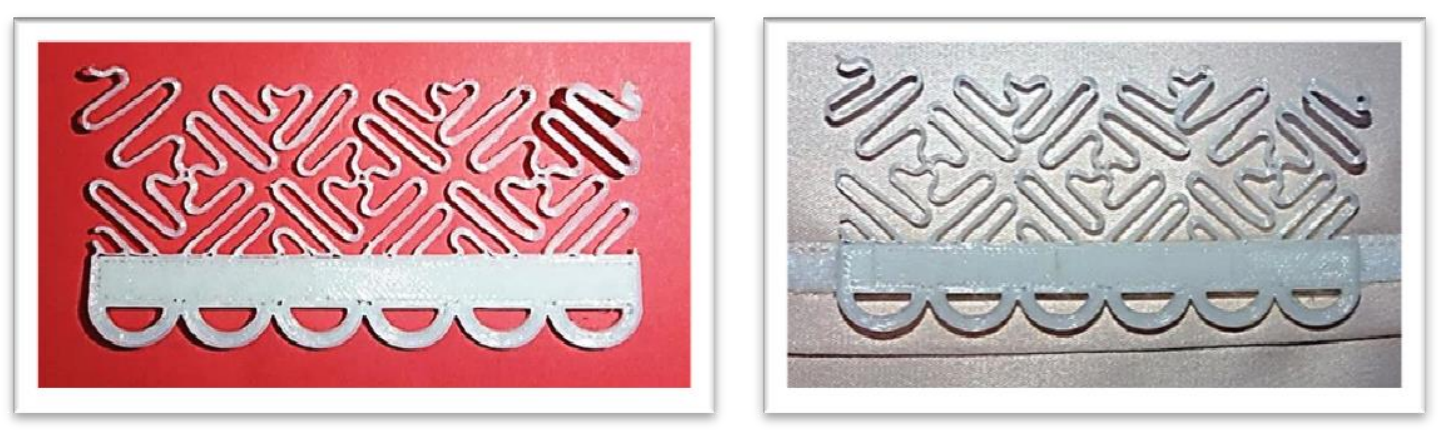

Figure 3. Sample the printed bookmark and product sequence with the applied printed mark

\section{CONCLUSIONS}

Although 3D printers are relatively expensive, they consume a considerable amount of energy during their work and require special knowledge of computer technology, it is obvious that their use for the creation of clothing is an innovative direction to diversify the look of clothing and is a method which allows to reduce the amount of waste due to the creation of the model in a software where the exact dimensions and form of the landmark are defined.

This technology also has the advantage of requiring a small workspace and, along with other features, 3D printing is beneficial to today's society that is looking for new, innovative, environmental friendly and personalized products, the research in question defining the possibility of creating clothing with $3 \mathrm{D}$ printed elements, with unique pieces of clothing combining traditional clothing industry and advanced technology innovation.

\section{REFERENCES}

[1] Alyson Vanderploeg, Seung-Eun Lee \& Michael Mamp; The application of 3D printing technology in the fashion industry, Available: http://www.tandfonline.com/doi/full/10.1080/17543266.2016.1223355; Accesat: 2017-0320.

[2] How many pounds of textiles do americans trash every year?, Available: http://www.ecouterre.com/infographic-how-many-pounds-of-textiles-do-americans-trashevery-year/, Accesat: 2017-09-12.

[3] 3D Fashion: New Research Project Wants the Fashion of the Future to be 3D Printed, Available: https://3dprint.com/130556/research-fashion-3d-printed/, Accesat: 2017-0912.

[4] Avantajele metodei de printare 3D, Available: http://www.printing3d.ro/avantaje/, Accesat: 2017-09-12.

[5] Verlan, V., Irovan, M. Dezvoltarea sortimentelor de îmbrăcăminte prin utilizarea tehnologiilor 3D. În: Conferința Tehnico-Științifică a Colaboratorilor, Doctoranzilor și Studenților, 1-14 decembrie, 2016/ Univ. Țehn. A Moldovei. - Chișinău: Tehnica-UTM̉, 2017. ISBN 978-9975-45-500-8. pp. 199-202.

[6] Verlan, V., Irovan, M. Particularitățile utilizării tehnologiei de imprimare 3D în domeniul confecțiilor. In: ,,Creativitate. Tehnologie. Marketing”, Simpozion Internațional $(4 ; 2017$; Chișinău). Creativitate. Tehnologie. Marketing: CTM 2017: Al IV-lea Simpozion internațional, 26-28 oct.: Culegere de articole/com. șt.: Viorel Bostan [et al.]. - Chișinău: S.n., 2017 (Tipogr. ,,Bons Offices”), ISBN 978-9975-45-505-3. pp. 233-238. 